\title{
Distinguishing prostate-specific antigen bounces from biochemical failure after low-dose-rate prostate brachytherapy
}

\author{
Cian Hackett, BSc, Sunita Ghosh, PhD, Ron Sloboda, PhD, Kevin Martell, MD, Lanna Lan, Nadeem Pervez, MBBS, \\ John Pedersen, MD, Don Yee, MD, Albert Murtha, MD, John Amanie, MD, Nawaid Usmani, MD \\ Department of Oncology, University of Alberta, Cross Cancer Institute, Edmonton, Alberta, Canada
}

\begin{abstract}
Purpose: The purpose of this study was to characterize benign prostate-specific antigen (PSA) bounces of at least $2.0 \mathrm{ng} / \mathrm{mL}$ and biochemical failure as defined by the Phoenix definition after prostate brachytherapy at our institution, and to investigate distinguishing features between three outcome groups: patients experiencing a benign PSA bounce, biochemical failure, or neither.

Material and methods: Five hundred and thirty consecutive men treated with low-dose-rate brachytherapy with follow-up of at least 3 years were divided into outcome groups experiencing bounce, failure, or neither. A benign bounce was defined as a rise of at least $2.0 \mathrm{ng} / \mathrm{mL}$ over the pre-rise nadir followed by a decline to $0.5 \mathrm{ng} / \mathrm{mL}$ or below, without intervention. Patient and tumor characteristics, treatment variables, and PSA kinetics were analyzed between groups.

Results: Thirty-two (6.0\%) men experienced benign bounces and 47 (8.9\%) men experienced failure. Men experiencing a bounce were younger $(p=0.01)$, had a higher 6-month PSA level $(p=0.03)$, and took longer to reach a final nadir $(p<0.01)$. Compared to the failure group, men with bounce had a lower pre-treatment PSA level $(p=0.01)$ and experienced a rise of at least $2.0 \mathrm{ng} / \mathrm{mL}$ that occurred sooner after the implant $(p<0.01)$ with a faster PSA doubling time $(p=0.01)$. Only time to PSA rise independently differentiated between bounce and failure $(p<0.01)$, with a benign bounce not being seen after 36 months post-treatment. Prostate-specific antigen levels during a bounce reached levels as high as $12.6 \mathrm{ng} / \mathrm{mL}$ in this cohort, and in some cases took over 5 years to decline to below $0.5 \mathrm{ng} / \mathrm{mL}$.

Conclusions: Although there is substantial overlap between the features of benign PSA bounces and failure, physicians may find it useful to evaluate the timing, absolute PSA level, initial response to treatment, and rate of rise when contemplating management for a PSA rise after low-dose-rate brachytherapy.
\end{abstract}

Key words: brachytherapy, prostatic neoplasms, prostate-specific antigen, relapse.

\section{Purpose}

Low-dose-rate (LDR) brachytherapy has excellent prostate-specific antigen (PSA) relapse-free survival outcomes compared to other treatment modalities [1-3]. Despite favorable outcomes, temporary increases in PSA levels are common, occurring in $15 \%$ to $84 \%$ of men receiving prostate brachytherapy [4]. These benign rises, termed PSA bounces, or PSA spikes, were first described in detail by Wallner in 1997 [5]. Since then, PSA bounces have been studied using a variety of definitions, typically increases over a previous PSA measurement, ranging from $0.1 \mathrm{ng} /$ $\mathrm{mL}$ to $4.0 \mathrm{ng} / \mathrm{mL}[4,6]$.

The Phoenix definition of biochemical failure which is triggered when a PSA level reaches $2.0 \mathrm{ng} / \mathrm{mL}$ over the nadir PSA [7], was developed for external beam radia- tion therapy, but is also commonly used to measure biochemical failure after brachytherapy [6,8-11]. While most studies use the PSA bounce definition suggested by Caloglu and Ciezki [4], a $0.2 \mathrm{ng} / \mathrm{mL}$ increase in PSA level followed by a subsequent decline below the prebounce level [12], few studies define a PSA bounce as one of a magnitude great enough to trigger the Phoenix definition $[6,8,10,11,13]$. Only one compares the characteristics of patients who experienced a PSA bounce of at least $2.0 \mathrm{ng} / \mathrm{mL}$ with those of patients whose PSA level rose by at least $2.0 \mathrm{ng} / \mathrm{mL}$ without a subsequent decline [10].

Prostate-specific antigen bounces of $0.1 \mathrm{ng} / \mathrm{mL}$ and $0.2 \mathrm{ng} / \mathrm{mL}$ have been found to predict better biochemical failure-free survival after prostate brachytherapy [14-19]. However, patients and clinicians may experience consid- 
erable anxiety when faced with a rise in PSA level great enough to satisfy the Phoenix definition of biochemical failure. The objectives of this study were to characterize the features of benign PSA bounces of at least $2.0 \mathrm{ng} /$ $\mathrm{mL}$ and biochemical failures as defined by the Phoenix definition at our institution, and to investigate associations between pre-treatment, treatment, and post-treatment variables and patients experiencing a benign PSA bounce, biochemical failure, or neither.

\section{Material and methods}

\section{Study population}

From September 1998 to August 2009, 710 consecutive men were treated with ${ }^{125} \mathrm{I}$ brachytherapy at the Cross Cancer Institute. Men with indolent disease (clinical stage $<$ T2b, PSA level $<10 \mathrm{ng} / \mathrm{mL}$, Gleason score $<7$, and $<3$ positive biopsy cores with a minimum sample of 6 cores), low-risk disease (clinical stage $<$ T2b, PSA level $<10 \mathrm{ng} / \mathrm{mL}$, and Gleason score $<7$ ), and low-tier intermediate-risk disease (one intermediate risk feature: either clinical stage of $\mathrm{T} 2 \mathrm{~b}$ or $\mathrm{T} 2 \mathrm{c}$, Gleason score $\geq 7$ or PSA of 10-20 ng/mL) were eligible for brachytherapy. Patients with a PSA follow-up time of less than 3 years and those receiving external beam radiation therapy (15) were excluded, for a study population of 530 patients. No patient died of prostate cancer within 3 years of implant.

\section{Treatment}

Patients were treated with ${ }^{125}$ I sources (model 6711; Oncura, Arlington Heights, IL and model MED3631-AM; North American Scientific, Chatsworth, CA, USA) using an implant technique that our group has previously described [20]. Briefly, a pre-operative planning ultrasound was utilized to create a modified peripheral loading pattern delivering a minimum peripheral dose of $145 \mathrm{~Gy}$ to the PTV. A transrectal ultrasound-guided transperineal technique under general or spinal anesthesia was used to deliver the sources. Post-operative dosimetry was assessed one month after the implant with computed tomography using the Variseed treatment planning system (Varian Medical Systems, Palo Alto, CA, USA). The Cross Cancer Institute switched from low $(0.4 \mathrm{U})$ to intermediate $(0.5 \mathrm{U})$ activity sources in 2002. One hundred and four (19.6\%) patients received neoadjuvant hormone therapy (NHT), for a median time of 4.73 months (range 1.0-18.5 months).

\section{Follow-up and data collection}

The follow-up care of these patients consisted of assessments at four weeks followed by semi-annual assessments for two years and then annually thereafter. Pre-treatment, treatment, and post-treatment variables were retrospectively entered into a database, last updated in August 2012. At our institution, a large proportion of patients travel significant distances for their treatment and are discharged with guidelines provided to local family physicians for follow-up including physical examinations, toxicity, and PSA assessments. In the province of Alberta, patients' electronic medical records contain all
PSA measurements performed within the province, allowing this data to be captured retrospectively in the database.

\section{Definitions and outcome groups}

A PSA rise was defined as an increase of at least $2.0 \mathrm{ng} / \mathrm{mL}$ in PSA level over a pre-rise nadir, the minimum PSA level between implant and a PSA rise. If the PSA rise was followed by a decrease to $\leq 0.5 \mathrm{ng} / \mathrm{mL}$ without intervention, it was considered a benign bounce. Duration was calculated from the first increase over the pre-rise nadir to the time at which the PSA level was $\leq 0.5 \mathrm{ng} / \mathrm{mL}$. The time to peak PSA was calculated from this first increase to the peak PSA level. Patients were considered to have failure if they experienced a PSA rise that was not a benign bounce, or received salvage treatment for a rising PSA. For these patients, the final nadir was defined as the lowest post-implant PSA level before failure.

Prostate-specific antigen rate of decline was calculated, excluding patients with a final nadir greater than or equal to the pre-treatment PSA level as well as all patients who received NHT, in patients without a PSA rise as the velocity from the pre-treatment PSA level to the final nadir, and in patients with a PSA rise, from the pre-treatment PSA level to the pre-rise nadir. Prostate-specific antigen doubling time was calculated assuming an exponential growth model, as $\ln (2) *\left(a_{1}-b_{1}\right) /\left(\ln \left(a_{2}\right)-\ln \left(b_{2}\right)\right)$, and PSA velocity was calculated as a mean velocity, $\left(a_{1}-b_{1}\right) /\left(a_{2}-b_{2}\right)$, where $a_{1}$ and $a_{2}$ represent the time and PSA level of the nadir $+2.0 \mathrm{ng} / \mathrm{mL}$ measurement, and $b_{1}$ and $b_{2}$ represent the time and PSA level of the last measurement before a PSA rise equal to the pre-rise nadir. Prostate-specific antigen doubling time and PSA velocity were also calculated using the peak PSA level rather than the nadir $+2.0 \mathrm{ng} / \mathrm{mL}$ measurement.

\section{Statistical analysis}

Three outcome groups were analyzed: those with benign bounce, those with failure, and those with neither a benign bounce nor failure. Descriptive statistics were used to present the study variables. Median and range were used for continuous variables; frequency and percentages were used for categorical variables. Binary logistic regression was used to determine the pre-treatment, treatment, and post-treatment factors associated with bounce vs. failure, as well as bounce vs. neither failure nor bounce. Univariate analysis was conducted to determine the factors associated with the outcome variable, and the factors significant at $p<0.10$ level were considered significant for inclusion in the multivariate model. The final model was chosen with only significant variables. Since we had multiple hypotheses, a $p$-value of 0.03 was chosen for significance level. SAS (SAS Institute Inc., Cary, NC USA version 9.3) was used to conduct all statistical analysis.

\section{Results}

Patient characteristics of the entire study cohort are shown in Table 1 . Thirty two $(6.0 \%)$ patients experienced a benign bounce, and $47(8.9 \%)$ patients experienced failure. Table 2 shows the variables compared between all 
three outcome groups. On univariate analysis comparing the bounce group to the group with neither bounce nor failure, bounce patients were younger $(p=0.0144)$, had a higher 6-month PSA level $(p=0.0345)$, a faster PSA rate of decline $(p<0.0001)$, more post-treatment PSA measurements $(p=0.0124)$, and took longer to reach a final nadir $(p<0.0001)$. A trend towards a greater $V_{200}$ in the bounce group approached statistical significance $(p=0.0604)$. After excluding the number of PSA measurements from the model, differences in the 6-month PSA level $(p=0.0065)$, the PSA rate of decline $(p<0.0001)$, and time to final nadir $(p<0.0001)$ remained significant on multivariate analysis.

Comparing bounce and failure groups, the bounce patients had a lower pre-treatment PSA level $(p=0.0132)$, a lower final nadir $(p=0.0009)$, a longer time to final nadir $(p=0.001)$, a shorter time to pre-rise nadir $(p=0.0066)$, a shorter time to PSA rise $(p=0.007)$, a faster PSA doubling time $(p=0.0114$ and $p=0.0143$ for the two definitions used), and more post-treatment PSA measurements $(p=0.0114)$. Prostate-specific antigen kinetics exclusive to patients experiencing a PSA rise are shown for bounce and failure groups in Table 3. Excluding the number of PSA measurements from the model, on multivariate analysis, only time to PSA rise independently differentiated between bounce and failure groups ( $p=0.0007)$.

The median times to PSA rise were 19.5 months and 48 months for the bounce and failure groups, respectively, as shown in Figure 1. Characteristics of bounces are shown in Figures 2 and 3. The median duration of bounce, from the first increase to the time when the PSA level was less than $0.5 \mathrm{ng} / \mathrm{mL}$, was 34 months (range 19-126 months). The median peak PSA level during bounce was $4.45 \mathrm{ng} / \mathrm{mL}$ (range $3.1-12.6 \mathrm{ng} / \mathrm{mL}$ ). The two largest PSA bounces reached peaks of $12.4 \mathrm{ng} / \mathrm{mL}$ and $12.6 \mathrm{ng} /$ $\mathrm{mL}$, magnitudes of 11.5 and $9.9 \mathrm{ng} / \mathrm{mL}$ above pre-rise nadirs, respectively. The median time from implant to the peak PSA was 22 months (range 11-36 months).

\section{Discussion}

Benign bounces of various magnitudes are common after prostate brachytherapy, and the frequency of bounce can depend on the study population and most importantly, the bounce definition used. In this population with a median follow-up time of 83 months, the frequency of a bounce of at least $2.0 \mathrm{ng} / \mathrm{mL}$ was $6.0 \%$, falling within the range of previously published frequencies of $2.5-9.8 \%$ in Table 4 . Bounce frequency and kinetics are affected by the frequency of PSA measurement and the length of minimum follow-up [13,21]. Given the reported timing of bounces of at least $2.0 \mathrm{ng} / \mathrm{mL}$, a minimum follow-up of 3 years should capture most, if not all bounces. However, in this study, some patients experienced a benign bounce 60 months after their PSA levels dropped below $0.5 \mathrm{ng} / \mathrm{mL}$, even after ignoring those with large gaps in follow-up. Therefore, it remains important to exercise caution to avoid misclassification of a benign bounce as biochemical failure during retrospective analysis.

Younger age is the factor most consistently found to predict for bounce (Table 4$)[10,11,13]$. In this study, it
Table 1. Patient characteristics. Data are represented as median (range), unless otherwise specified

\begin{tabular}{lc}
\hline Characteristic & All patients $(n=530)$ \\
\hline Age at implant (years) & $64.1(48.1-79.4)$ \\
\hline Risk group incidence (\%) & $200(37.7)$ \\
\hline Indolent & $206(38.9)$ \\
\hline Low & $124(23.4)$ \\
\hline Low-tier intermediate & $33.3(6.7-100.0)$ \\
\hline Percentage positive biopsy cores (\%) & $176(33.2)$ \\
\hline Bilateral disease incidence (\%) & $335(63.2)$ \\
\hline Yes & $81(15.3)$ \\
\hline No & $6.1(0.28-17.3)$ \\
\hline Unknown & $42.9(15.8-83.7)$ \\
\hline Pre-treatment PSA level (ng/mL) & $104(19.6)$ \\
\hline Prostate volume on TRUS (cc) & $425(80.2)$ \\
\hline Hormone therapy incidence $(\%)$ & $1(0.2)$ \\
\hline Yes & \\
\hline No & $158(29.8)$ \\
\hline Unknown & $372(70.2)$ \\
\hline Source strength (U) incidence $(\%)$ & $152.38(57.0-274.2)$ \\
\hline$\leq 0.445$ & $92.8(25.5-100)$ \\
\hline$>0.445$ & $51.5(8.9-97.4)$ \\
\hline$D_{90}(G y)$ & $22.8(3.7-86.8)$ \\
\hline$V_{100}(\%)$ & $83(36-179)$ \\
\hline$V_{150}(\%)$ & $9(12)$ \\
\hline$V_{200}(\%)$ & \\
\hline PSA follow-up (months) & \\
\hline Number of PSA measurements & \\
\hline
\end{tabular}

may have been related to another variable such as the 6-month PSA level or PSA rate of decline, given its significance on univariate, but not multivariate analysis. Though post-implant PSA levels do not correspond to sexual activity or testosterone levels [22-24], the presence of residual epithelial tissue susceptible to a higher baseline testosterone level in younger patients may explain both the association between bounce and younger age, and a higher pre-rise PSA nadir before bounce compared to failure [10].

The most likely etiologies of benign bounce are late radiation-induced effects on PSA-producing epithelium, either prostatitis, tissue necrosis or both $[10,25,26]$. Associations between large prostate volumes and bounce rates $[18,25]$ might support these etiologies, but are not supported by this study, nor other investigations of bounces of at least $2.0 \mathrm{ng} / \mathrm{mL}[6,8,10,11,13]$. Size effects unrelated to dosimetry may not effect bounce, but in this study, a trend towards greater $V_{200}$ in bounce patients compared to those experiencing neither bounce nor failure was close to statistical significance $(p=0.0604)$, whereas a similar large cohort study has previously found a similar trend between bounce patients and failure patients [10]. This association may become clearer in larger cohort or multiinstitutional studies. Along with a recent study showing diffuse prostatic activity in MRI scans during benign 
Table 2. Pre-treatment, treatment and post-treatment characteristics compared between all three outcome groups. Data are represented as median (range), unless otherwise specified

\begin{tabular}{|c|c|c|c|}
\hline Characteristic & Bounce $(n=32)$ & Failure $(n=47)$ & $\begin{array}{c}\text { Neither bounce } \\
\text { nor failure }(n=451)\end{array}$ \\
\hline Age at implant (years) & $62.0(48.2-73.8)^{1}$ & $62.7(51.9-75.9)$ & $64.9(48.1-79.4)^{1}$ \\
\hline \multicolumn{4}{|l|}{ Risk group incidence (\%) } \\
\hline Indolent & $11(33.3)$ & $18(38.4)$ & $171(38.4)$ \\
\hline Low & $15(48.5)$ & $16(38.2)$ & $175(38.2)$ \\
\hline Low-tier intermediate & $6(18.2)$ & $13(23.5)$ & $105(23.5)$ \\
\hline Percentage positive biopsy cores (\%) & $30.8(7.7-100.0)$ & $29.3(7.7-100.0)$ & $33.3(6.7-100.0)$ \\
\hline \multicolumn{4}{|l|}{ Bilateral disease incidence (\%) } \\
\hline Yes & $12(39.4)$ & $14(32.7)$ & $150(32.7)$ \\
\hline No & $19(57.6)$ & $31(63.7)$ & $285(63.7)$ \\
\hline Unknown & $1(3.0)$ & $2(3.7)$ & $16(3.7)$ \\
\hline Pre-treatment PSA level (ng/mL) & $5.75(1.8-12.1)^{2}$ & $7.3(0.28-13)^{2}$ & $6(0.28-17.3)$ \\
\hline Prostate volume on TRUS (cc) & $43.6(27.0-74.4)$ & $41.1(19.4-62.1)$ & $42.9(15.8-83.7)$ \\
\hline \multicolumn{4}{|l|}{ Hormone therapy incidence (\%) } \\
\hline Yes & $4(12.1)$ & $9(20.2)$ & $91(20.2)$ \\
\hline No & $28(87.9)$ & $38(79.6)$ & $359(79.6)$ \\
\hline Unknown & $0(0.0)$ & $0(0.0)$ & $1(0.2)$ \\
\hline \multicolumn{4}{|l|}{ Source strength (U) incidence (\%) } \\
\hline$\leq 0.445$ & $11(36.4)$ & $23(48.9)$ & $124(29.6)$ \\
\hline$>0.445$ & $21(63.6)$ & $24(51.1)$ & $327(70.4)$ \\
\hline$D_{90}$ & $154.1(117.4-195.6)$ & $151.9(57.0-207.2)$ & $152.4(79.2-274.2)$ \\
\hline$V_{100}$ & $93.4(78.2-99.5)$ & $93.2(58.6-99.8)$ & $92.8(25.5-100.0)$ \\
\hline $\mathrm{V}_{150}$ & $60.8(29.4-79.2)$ & $50.2(26.3-86.9)$ & $51.5(8.9-97.4)$ \\
\hline$V_{200}$ & $31.0(11.4-46.7)$ & $23.5(11.3-54.3)$ & $22.3(3.7-86.8)$ \\
\hline PSA follow-up (months) & $75(40-158)$ & $102(36-160)$ & $82(36-179)$ \\
\hline Number of PSA measurements & $12(4-20)^{1,2}$ & $16(6-42)^{2}$ & $9(1-27)^{1}$ \\
\hline 6-month PSA level (ng/mL) & $1.6(1.1-3.5)^{1,3}$ & $1.5(0.57-12)$ & $0.87(0.1-5.9)^{1,3}$ \\
\hline PSA rate of decline (ng/mL/month) & $0.231(0.012-1.045)^{1,3}$ & $0.385(0.068-2.300)$ & $0.131(0.008-2.533)^{1,3}$ \\
\hline Final nadir, PSA level & $0.1(0.1-0.5)^{2}$ & $0.92(0.1-11.8)^{2}$ & $0.1(0.1-1.7)$ \\
\hline Time to final PSA nadir (months) & $64(40-138)^{1,2,3}$ & $11(3-60)^{2}$ & $45(2-159)^{1,3}$ \\
\hline
\end{tabular}

${ }^{1}$ Significant on univariate logistic regression analysis between bounce and neither groups

${ }^{2}$ Significant on univariate logistic regression analysis between bounce and failure groups

${ }^{3}$ Significant on multivariate analysis between bounce and neither groups

Table 3. Post-treatment characteristics, bounce and failure groups. Data are represented as median (range), unless otherwise specified

\begin{tabular}{lcc} 
Characteristic & Bounce $(n=32)$ & Failure $(n=47)$ \\
\hline Pre-rise nadir, PSA level $(\mathrm{ng} / \mathrm{mL})$ & $1.2(0.1-2.7)$ & $0.97(0.1-11.8)$ \\
\hline Time to pre-rise nadir (months) & $6.5(3-19)^{1}$ & $11(3-60)^{1}$ \\
\hline Time from implant to nadir +2.0 $\mathrm{ng} / \mathrm{mL}$ (months) & $19.5(11-36)^{1,2}$ & $48(7-144)^{1,2}$ \\
\hline Doubling time, pre-rise nadir to nadir +2.0 $\mathrm{ng} / \mathrm{mL}$ (months) & $6.3(2.9-23.7)^{1}$ & $10.8(1.7-45.2)^{1}$ \\
\hline Doubling time, pre-rise nadir to peak PSA level (months) & $7.1(2.9-23.7)^{1}$ & $11.3(1.9-38.3)^{1}$ \\
\hline PSA velocity, pre-rise nadir to nadir +2.0 $\mathrm{ng} / \mathrm{mL}$ (ng/mL/month) & $0.25(0.09-1.05)$ & $0.12(0.02-5.17)$ \\
\hline PSA velocity, pre-rise nadir to peak PSA level (ng/mL/month) & $0.22(0.09-1.05)$ & $0.22(0.04-15.30)$
\end{tabular}

${ }^{1}$ Significant on univariate logistic regression analysis between bounce and failure groups

2Significant on multivariate analysis between bounce and failure groups 


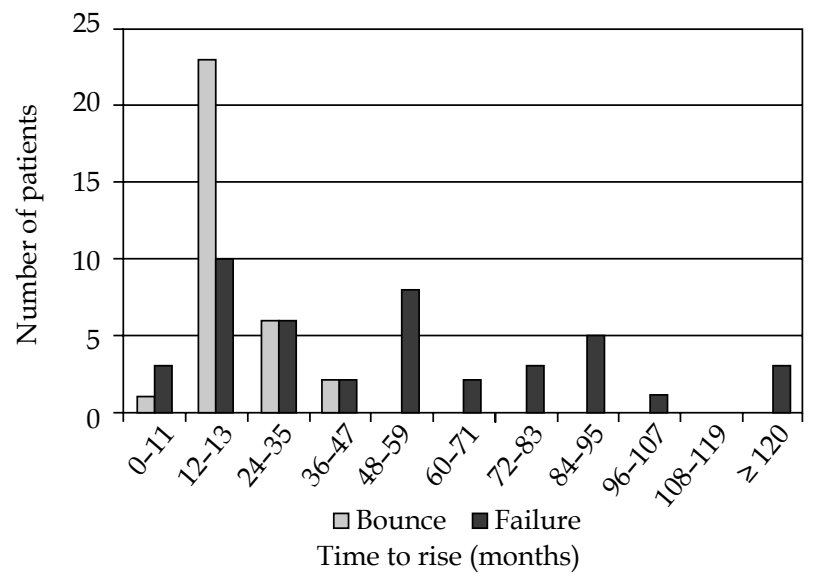

Fig. 1. Time from implant to a PSA rise of at least $2.0 \mathrm{ng} / \mathrm{mL}$ for patients experiencing either a benign bounce or failure

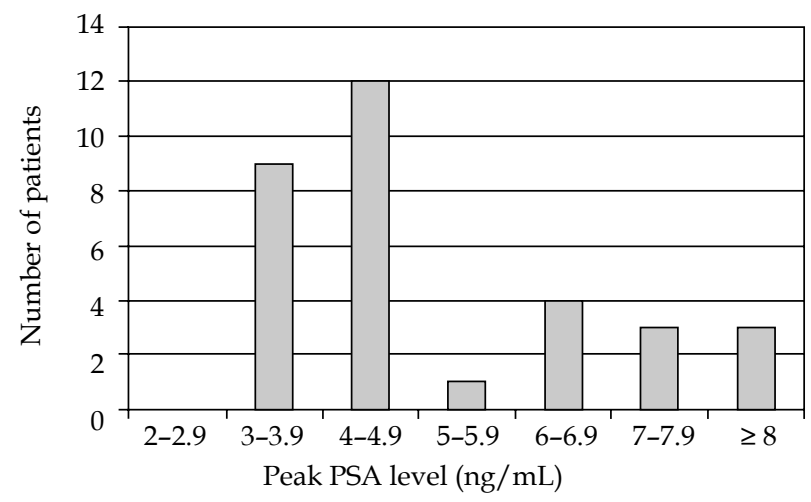

Fig. 3. Peak PSA level during bounce

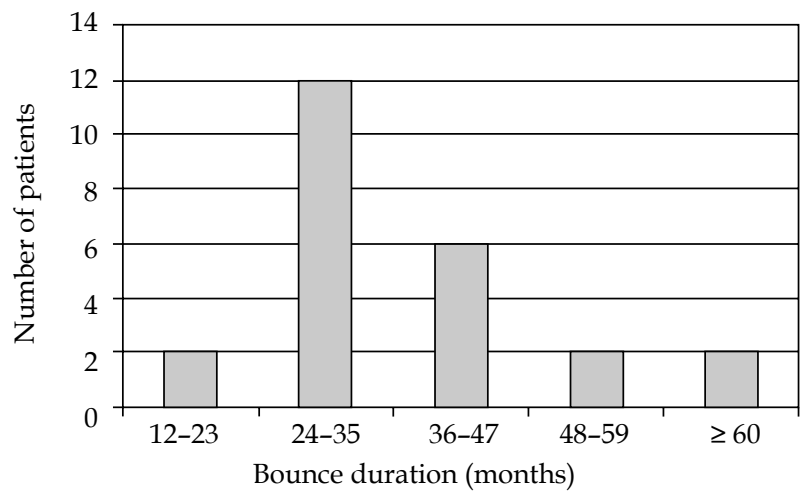

Fig. 2. Duration of benign bounce, from the first increase over the pre-rise nadir to the time at which the PSA level was $\leq 0.5 \mathrm{ng} / \mathrm{mL}$

bounce compared with focal activity during recurrence [27], this may provide evidence for PSA hyperproduction or release from heavily irradiated areas. Though there was no significant difference between the means, the low $\mathrm{D}_{90}$ of some failed implants (range 57.0-207.2, Table 2) compared to the bounce group (range 117.4-195.6, Table 2) may be explained by $\mathrm{D}_{90}$ as a previously published predictive factor for biochemical failure [28].

Although the patient groups experiencing bounce and neither bounce nor failure had similar pre-treatment PSA levels, a higher 6-month PSA level as an independent predictor of bounce may be attributed to a slower initial response to treatment, leaving residual PSA-producing epithelium accounting for PSA bounce. The time to trigger the definition of biochemical failure remains the most distinguishing feature of a benign bounce (Table 4).

Table 4. Reported results from studies of PSA bounces of at least $2.0 \mathrm{ng} / \mathrm{mL}$ after prostate brachytherapy

\begin{tabular}{|c|c|c|c|c|c|c|c|}
\hline $\begin{array}{l}\text { Authors, } \\
\text { year }\end{array}$ & Patients & $\begin{array}{l}\text { Frequency } \\
\text { of bounce } \\
\text { of } 2.0 \mathrm{ng} / \mathrm{mL}\end{array}$ & $\begin{array}{l}\text { Time to occurrence, } \\
\text { median in months } \\
\text { (range) }\end{array}$ & $\begin{array}{c}\text { Median } \\
\text { magnitude, } \\
\mathrm{ng} / \mathrm{mL} \text { (range) }\end{array}$ & $\begin{array}{l}\text { Factors } \\
\text { predicting } \\
\text { bounce }\end{array}$ & Failure rate & $\begin{array}{l}\text { Factors differ- } \\
\text { entiating failure } \\
\text { from bounce }\end{array}$ \\
\hline $\begin{array}{l}\text { Crook } \\
\text { et al., } \\
2007[13]\end{array}$ & 292 & $5.8 \%$ & $15.2(3-29)$ & $\begin{array}{c}0.76 \\
(0.21-11.79)^{1}\end{array}$ & Younger age ${ }^{1}$ & $\begin{array}{l}\text { 2.9\%, median } \\
\text { follow-up } \\
44 \text { months }\end{array}$ & $\begin{array}{c}\text { Time to } \\
\text { occurrence }^{1}\end{array}$ \\
\hline $\begin{array}{l}\text { Bachand } \\
\text { et al., } \\
2009 \text { [8] }\end{array}$ & $153^{2}$ & $9.8 \%$ & 15.2 (NA) & 3.21 (NA) & NA & $\begin{array}{l}\text { 6.4\%, median } \\
\text { follow-up } \\
44 \text { months }\end{array}$ & NA \\
\hline $\begin{array}{l}\text { McGrath } \\
\text { et al., } \\
2010[6]\end{array}$ & $691^{2}$ & $3.0 \%$ & NA & 2.6 (NA) & NA & $\begin{array}{l}\text { NA, median } \\
\text { follow-up } \\
48 \text { months }\end{array}$ & NA \\
\hline $\begin{array}{l}\text { Thompson } \\
\text { et al., } \\
2010 \text { [10] }\end{array}$ & 1006 & $2.5 \%$ & $20(6-36)$ & 3.1 (NA-9) & Younger age & $\begin{array}{l}3.2 \% \text {, median } \\
\text { follow-up } \\
54 \text { months }\end{array}$ & $\begin{array}{l}\text { Younger age, } \\
\text { time to } \\
\text { occurrence }\end{array}$ \\
\hline $\begin{array}{l}\text { Mazeron } \\
\text { et al., } \\
2012[11]\end{array}$ & 198 & $4.5 \%$ & $17.9(3.6-24.2)$ & $2.5(2.1-5.1)$ & $\begin{array}{c}\text { Younger age, } \\
\text { higher PSA value } \\
\text { at } 6 \text { weeks }\end{array}$ & $\begin{array}{l}\text { 7.1\%, median } \\
\text { follow-up } \\
64 \text { months }\end{array}$ & None \\
\hline $\begin{array}{l}\text { Hackett } \\
\text { et al. - this } \\
\text { study }\end{array}$ & 530 & $6.0 \%$ & $19.5(11-36)$ & $3.0(2.1-11.5)$ & $\begin{array}{l}\text { 6-month PSA } \\
\text { level, PSA rate of } \\
\text { decline, time to } \\
\text { final nadir }\end{array}$ & $\begin{array}{l}\text { 8.9\%, median } \\
\text { follow-up } \\
83 \text { months }\end{array}$ & $\begin{array}{l}\text { Time to } \\
\text { occurrence }\end{array}$ \\
\hline
\end{tabular}

${ }^{1}$ Included bounce magnitudes under $2.0 \mathrm{ng} / \mathrm{mL}$

Included HDR brachytherapy patients and HDR brachytherapy with EBRT

NA - Not available 
Although most (62.7\%) PSA rises of at least $2.0 \mathrm{ng} / \mathrm{mL}$ occurring at 36 months or less after brachytherapy were benign bounces in our cohort, there remains substantial overlap in the timing of bounce and failure. With this degree of uncertainty in any PSA rise of at least $2.0 \mathrm{ng} /$ $\mathrm{mL}$ in the three years following brachytherapy, most clinicians will monitor the patient and use PSA kinetics to guide treatment decisions, given the low sensitivity of bone scans and feasibility of MR imaging for bone metastases [29], as well as the inaccuracy of prostate biopsy after brachytherapy $[8,30]$. In our population, most patients with a benign bounce experienced an increase of less than $4.0 \mathrm{ng} / \mathrm{mL}$ over the pre-rise nadir, but the magnitude of the largest benign bounce was $11.5 \mathrm{ng} / \mathrm{mL}$, close to the maximum magnitude previously reported [13]. Treatment before a PSA increase of this magnitude may subject a patient to unnecessary side effects and risks, whereas delaying treatment in patients with true failure allows time for disease progression. Faced with an increasing PSA level, patients and physicians may find it useful to understand the duration of a benign bounce. The duration of bounce from the first increase over a pre-rise nadir to the time when the PSA level was $\leq 0.5 \mathrm{ng} / \mathrm{mL}$ was 34 months, although most patients reached a peak PSA level within a year from the first increase. In fact, the time from implant to the peak PSA level, 22 months, is similar to the time to bounce, 19.5 months, and the bounce duration is largely a result of a lengthy decline to a PSA $\leq 0.5 \mathrm{ng} / \mathrm{mL}$. McGrath et al. found that hormone therapy increased the duration of a benign bounce [6]. The effect of NHT on bounce duration was difficult to analyze in our study, with only four patients who experienced bounce having received NHT, and having similar bounce durations to the hormone-naïve patients. Additionally, the use of NHT was not significantly different in the bounce group compared to the failure group and compared to the group experiencing neither bounce nor failure.

In addition to characterizing PSA rises in terms of timing, magnitude, and duration, it may be useful to calculate a rate of increase. In our study, two different methods of calculating doubling time were used, both of which yielded statistically significantly shorter PSA doubling times for patients experiencing benign bounce than for patients experiencing failure. Although this result agrees with the comparison made by Thompson et al. [10], the doubling time is longer for both outcome groups and is instead similar to that reported by Mazeron et al. [11]. Despite this difference, a greater range of rates of increase is found among patients experiencing failure, and extremely high rates of increase are only found in failure. After finding a maximum PSA velocity of $0.98 \mathrm{ng} / \mathrm{mL} /$ month during bounces of at least $0.2 \mathrm{ng} / \mathrm{mL}$, Mitchell et al. concluded that all patients with a velocity over $1.0 \mathrm{ng} / \mathrm{mL} /$ month are likely failures [22], which is supported by our maximum PSA velocity during bounce of $1.045 \mathrm{ng} / \mathrm{mL} /$ month.

\section{Conclusions}

In this study's cohort of 530 patients receiving lowdose-rate prostate brachytherapy, $6.0 \%$ experienced a be- nign PSA bounce of at least $2.0 \mathrm{ng} / \mathrm{mL}$ that fulfilled the Phoenix definition of biochemical failure, and $8.9 \%$ experienced true failure. Although the etiology of bounce after brachytherapy remains unknown, patients with a bounce were younger, had higher PSA levels 6 months post-treatment, and took longer to reach a final nadir than patients with neither bounce nor failure. Prostate-specific antigen kinetics during bounce in our patient population matched those published by others. Bounce patients experienced a PSA rise much earlier and one that rose faster than most failure patients, although no bounce was found after 36 months post-implant, none exceeded a PSA level of $12.6 \mathrm{ng} / \mathrm{mL}$, and none rose faster than $1.045 \mathrm{ng} / \mathrm{mL} /$ month in our cohort. These results support an approach that combines continued monitoring with evaluation of timing, magnitude and rate of rise when faced with a PSA increase after prostate brachytherapy.

\section{Acknowledgements}

We thank the Edmonton brachytherapy team for providing excellent care. Cian Hackett received financial support for this work from Alberta Innovates - Health Solutions.

\section{Disclosure}

Authors report no conflict of interest.

\section{References}

1. Kupelian PA, Potters L, Khuntia D et al. Radical prostatectomy, external beam radiotherapy $<72 \mathrm{~Gy}$, external beam radiotherapy $\geq 72 \mathrm{~Gy}$, permanent seed implantation, or combined seeds/external beam radiotherapy for stage T1-T2 prostate cancer. Int J Radiat Oncol Biol Phys 2004; 58: 25-33.

2. Jabbari S, Weinberg VK, Katsuto $S$ et al. Equivalent biochemical control and improved prostate-specific antigen nadir after permanent prostate seed implant brachytherapy versus highdose three-dimensional conformal radiotherapy and highdose conformal proton beam radiotherapy boost. Int J Radiat Oncol Biol Phys 2010; 76: 36-42.

3. Zelefsky MJ, Yamada Y, Pei X et al. Comparison of tumor control and toxicity outcomes of high-dose intensity-modulated radiotherapy and brachytherapy for patients with favorable risk prostate cancer. Urology 2011; 77: 986-990.

4. Caloglu M, Ciezki J. Prostate-specific antigen bounce after prostate brachytherapy: review of a confusing phenomenon. Urology 2009; 74: 1183-1190.

5. Wallner KE, Blasko J, Dattoli MG. Prostate brachytherapy made complicated. SmartMedicine Press, Seattle 1997; 14.11-14.15.

6. McGrath SD, Antonucci JV, Fitch DL et al. PSA bounce after prostate brachytherapy with or without neoadjuvant androgen deprivation. Brachytherapy 2010; 9: 137-144.

7. Roach III M, Hanks G, Thames J et al. Defining biochemical failure following radiotherapy with or without hormonal therapy in men with clinically localized prostate cancer: recommendations of the RTOG-ASTRO Phoenix consensus conference. Int J Radiat Oncol Biol Phys 2006; 65: 965-974.

8. Bachand F, Martin AG, Beaulieu L et al. An eight-year experience of HDR brachytherapy boost for localized prostate cancer: biopsy and PSA outcome. Int J Radiat Oncol Biol Phys 2009; 73: 679-684.

9. Pinkawa M, Piroth MD, Holy R et al. Prostate-specific antigen kinetics following external-beam radiotherapy and tem- 
porary (Ir-192) or permanent (I-125) brachytherapy for prostate cancer. Radiother Oncol 2010; 96: 25-29.

10. Thompson A, Keyes M, Pickles T et al. Evaluating the Phoenix definition of biochemical failure after 125I prostate brachytherapy: can PSA kinetics distinguish PSA failures from PSA bounces? Int J Radiat Oncol Biol Phys 2010; 78: 415-421.

11. Mazeron R, Bajard A, Montbarbon X et al. Permanent 125Iseed prostate brachytherapy: early prostate specific antigen value as a predictor of PSA bounce occurrence. Radiat Oncol 2012; 7: 46.

12. Gaztanaga M, Crook J. Interpreting a rising prostate-specific antigen after brachytherapy for prostate cancer. Int J Urol 2013; 20: 142-147.

13. Crook J, Gillan C, Yeung I et al. PSA kinetics and PSA bounce following permanent seed prostate brachytherapy. Int J Radiat Oncol Biol Phys 2007; 69: 426-433.

14. Critz FA, Williams WH, Levinson AK et al. Prostate specific antigen bounce after simultaneous irradiation for prostate cancer: The relationship to patient age. J Urol 2003; 170: 18641867.

15. Aaltomaa SH, Kataja VV, Raty A et al. Does the outcome of prostate cancer patients with large prostates differ from small prostate size in permanent seed, low dose-rate brachytherapy? Scand J Urol Nephrol 2011; 45: 339-345.

16. Caloglu M, Ciezki JP, Reddy CA et al. PSA bounce and biochemical failure after brachytherapy for prostate cancer: A study of 820 patients with a minimum of 3 years of follow-up. Int J Radiat Oncol Biol Phys 2011; 80: 735-741.

17. Hinnen KA, Monninkhof EM, Battermann JJ et al. Prostate specific antigen bounce is related to overall survival in prostate brachytherapy. Int J Radiat Oncol Biol Phys 2012; 82: 883-888.

18. Zwahlen DR, Smith R, Andrianopoulos N et al. Prostate-specific antigen bounce after permanent iodine-125 prostate brachytherapy - an Australian analysis. Int J Radiat Oncol Biol Phys 2011; 79: 179-187.

19. Bernstein MB, Ohri N, Hodge JW et al. Prostate-specific antigen bounce predicts for a favorable prognosis following brachytherapy: a meta-analysis. J Contemp Brachytherapy 2013; 5: $210-214$

20. Sloboda RS, Pedersen J, Halperin R. Is there a preferred strength for regularly spaced 125I seeds in inverse-planned prostate implants? Int J Radiat Oncol Biol Phys 2003; 55: 234-244.

21. Zietman AL, Christodouleas JP, Shipley WU. PSA bounces after neoadjuvant androgen deprivation and external beam radiation: impact on definitions of failure. Int J Radiat Oncol Biol Phys 2005; 62: 714-718.

22. Mitchell DM, Swindell R, Elliott $\mathrm{T}$ et al. Analysis of prostate-specific antigen bounce after I125 permanent seed implant for localised prostate cancer. Radiother Oncol 2008; 88: 102-107.

23. Taira AV, Merrick GS, Galbreath RW et al. Serum testosterone kinetics after brachytherapy for clinically localized prostate cancer. Int J Radiat Oncol Biol Phys 2012; 82: e33-e38.

24. Pickles T. Prostate-specific antigen (PSA) bounce and other fluctuations: which biochemical relapse definition is least prone to PSA false calls? An analysis of 2030 men treated for prostate cancer with external beam or brachytherapy with or without adjuvant androgen deprivation therapy. Int J Radiat Oncol Biol Phys 2006; 64: 1355-1359.

25. Satoh T, Ishiyama H, Matsumoto K et al. Prostate-specific antigen 'bounce' after permanent 125I-implant brachytherapy in Japanese men: a multi-institutional pooled analysis. BJU Int 2009; 103: 1064-1068.

26. Cavanagh W, Blasko JC, Grimm PD et al. Transient elevation of serum prostate-specific antigen following 125I/103Pd brachytherapy for localized prostate cancer. Semin Urol Oncol 2000; 18: 160-165.
27. Kirilova A, Damyanovich A, Crook J et al. 3D MR-spectroscopic imaging assessment of metabolic activity in the prostate during the PSA "bounce" following 125iodine brachytherapy. Int J Radiat Oncol Biol Phys 2011; 79: 371-378.

28. Stock RG, Stone NN, Tabert A et al. A dose-response study for I-125 prostate implants. Int J Radiat Oncol Biol Phys 1998; 41: 101-108.

29. Tombal B, Lecouvet F. Modern detection of prostate cancer's bone metastasis: is the bone scan era over? Adv Urol 2012; 2012: 1 .

30. Reed D, Wallner K, Merrick G et al. Clinical correlates to PSA spikes and positive repeat biopsies after prostate brachytherapy. Urology 2003; 62: 683-688. 